\title{
Dopamine reduces the receptor binding activity and not the secretion rate of placental lactogen in vitro
}

\author{
G. Thordarson and Isabel A. Forsyth \\ National Institute for Research in Dairying, Shinfield, Reading, Berks RG2 9AT, U.K.
}

\begin{abstract}
Summary. Incubation with high concentrations of dopamine $\left(\geqslant 10^{-3} \mathrm{~mol} / \mathrm{l}\right)$ depressed the ability of goat placental lactogen, human placental lactogen, ovine prolactin and human growth hormone to compete with labelled hormone in radioreceptor assays for lactogenic activity, with the greatest effects on placental lactogen. The activity of ovine prolactin in a radioimmunoassay was also depressed. The effects on human placental lactogen depended on the concentration of dopamine and on the time and temperature of incubation. Therefore, effects on activity, rather than on secretion rate, appear to explain the inhibition by dopamine of placental lactogen in the medium of placental explant cultures.
\end{abstract}

\section{Introduction}

Several lines of evidence have suggested that a dopaminergic mechanism could be involved in the regulation of placental lactogen secretion. In vivo, ewes injected with the dopamine agonist, bromocriptine, show increased concentrations of placental lactogen in cotyledons up to Day 100 of pregnancy (Martal \& Lacroix, 1978). Bromocriptine administration is associated with decreased plasma concentrations of placental lactogen in sheep (Lowe et al., 1979) and goats (Buttle, Cowie, Jones \& Turvey, 1979; T. J. Hayden, E. J. Brougham, S. V. Smith \& I. A. Forsyth, unpublished observations), although this effect is not reproducible (I. A. Forsyth, J. C. Byatt, \& S. Iley, unpublished observations) and does not occur after infusion of apomorphine (Marti-Henneberg, Gluckman, Isaac, Kaplan \& Grumbach, 1981). In vitro, a marked effect of dopamine $\left(10^{-3} \mathrm{~mol} / 1\right)$ in reducing levels of placental lactogen in cultures of human placenta was reported by Macaron, Famuyiwa \& Singh (1978), an effect confirmed using bovine placenta (Forsyth \& Hayden, 1980). We were, however, disturbed by the very high concentrations of dopamine needed to produce an effect, some 1000-fold greater than the amounts of dopamine that depress the secretion of prolactin from pituitary cells in vitro (Yeo, Thorner, Jones, Lowry \& Besser, 1979). We have now investigated the ability of dopamine to affect the binding of placental lactogen to receptors.

\section{Materials and Methods}

Materials. Single-strength Medium 199 was obtained from Wellcome Reagents, (Beckenham, Kent, U.K.), or from Gibco (Paisley, U.K.). It contained 100-200 units penicillin/ml, $100 \mu \mathrm{g}$ streptomycin $/ \mathrm{ml}$ and $0.25 \mu \mathrm{g}$ amphotericin $\mathrm{B} / \mathrm{ml}$. When incubations were carried out in air, the medium was buffered with $20 \mathrm{~mm}$-Hepes/1 $\left(N\right.$-2-hydroxyethylpiperazine- $N^{\prime}$-2-ethanesulphonic acid: Sigma Chemical Co., St Louis, MO, U.S.A.). Dopamine was from Sigma Chemical Co., Lascorbic acid from British Drug Houses (Poole, U.K.) and human placental lactogen (assay 95\%, Control No. 3359) from Nutritional Biochemicals Corporation (Cleveland, OH, U.S.A.). The following were received as gifts: bromocriptine from Professor E. Flückiger, Sandoz, Basle, Switzerland; ovine prolactin (NIH-P-S-12, 35 i.u./mg) from NIADDK, U.S.A.; human growth 
hormone from Dr P. J. Lowry, St Bartholomew's Hospital, London, U.K.; and goat placental lactogen from Dr T. J. Hayden, Department of Zoology, University College, Dublin, Ireland.

Dopamine, L-ascorbic acid and goat placental lactogen were dissolved directly in medium or buffer. Bromocriptine was dissolved in absolute ethanol and diluted so that the final solution contained not more than $1 \%$ alcohol. Ovine prolactin, human placental lactogen and human growth hormone were dissolved in a minimum quantity of $0.01 \mathrm{M}-\mathrm{NaOH}$ and diluted to the desired final concentration.

Incubation of placenta. Placentomes were collected into dry sterile containers from British Saanen goats and from Friesian cows killed in the second half of gestation. Within $15 \mathrm{~min}$, the placentomes were transferred to dishes containing Medium 199 buffered with Hepes (pH 7·2-7.4). In some experiments the medium contained dopamine $\left(10^{-7} \mathrm{~mol} / 1\right.$; see 'Results'). The placentomes were cut into $1 \mathrm{~cm}^{3}$ pieces. The fetal cotyledonary tissue was separated from maternal caruncle and cut further into pieces (mean wet weight $3.4 \mathrm{mg}$, range $1-5 \mathrm{mg}$ ). These were placed, one per well, in $1 \mathrm{ml}$ Medium 199 in polystyrene culture dishes (25-well dishes: Sterilin, Teddington, Middlesex, U.K.). All treatments were replicated 5 times. Incubation was at $37^{\circ} \mathrm{C}$ in $95 \%$ oxygen: $5 \%$ carbon

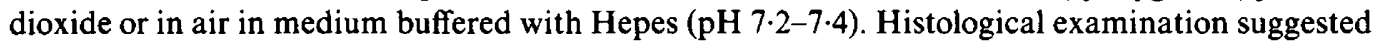
that tissue survival was improved by incubation in $95 \%$ oxygen, but the results obtained were not influenced by the atmosphere used. The medium was changed after a pre-culture period of $2-6 \mathrm{~h}$ to remove hormone leached from tissue damaged in dissection. In most experiments the tissue was incubated for a further $24 \mathrm{~h}$ before the medium and tissue were collected and the tissue was weighed on a Cahn balance. The medium was stored frozen at $-20^{\circ} \mathrm{C}$ until assayed for activity by a radioreceptor assay.

Extraction of placenta. A cotyledon from a goat on Day 118 of pregnancy was roughly chopped and divided into three 2-g portions. One portion was homogenized using a Silverson homogenizer in $8 \mathrm{ml}$ Medium 199 and two portions in the same volume of Medium $199+20 \mathrm{mmol} \mathrm{Hepes} / 1+$ $0.1 \%$ ascorbic acid $+1 \mathrm{mmol}$ dopamine $/ 1$. One of these was incubated for $24 \mathrm{~h}$ at $37^{\circ} \mathrm{C}$ before centrifugation at $22000 \mathrm{~g}$ for $30 \mathrm{~min}$. The other two portions were centrifuged immediately. Supernatants were collected and stored at $-20^{\circ} \mathrm{C}$ until assayed by radioreceptor assay.

Radioreceptor assay. The activity of placental lactogen in tissues and in culture medium and of ovine prolactin, human growth hormone and human placental lactogen was estimated using radioreceptor assays as previously described (Hayden, Thomas, Smith \& Forsyth, 1980). The receptors were prepared from rabbit liver (Parke \& Forsyth, 1975; Text-fig. 1 only) or rabbit mammary gland (Shiu, Kelly \& Friesen, 1973) and were freeze-dried. Tracer was prepared by labelling ovine prolactin or human growth hormone (Text-fig. $3 \mathrm{~b}$ only) with ${ }^{125} \mathrm{I}$ and the same hormones or human placental lactogen were used as standards (see 'Results'). All results are expressed as ng equivalents of standard per $\mathrm{ml}$ or per $\mathrm{mg}$ wet tissue weight as appropriate. Medium 199 was found to depress the binding of ${ }^{125} \mathrm{I}$-labelled ovine prolactin to receptors, so for assays on medium samples the standards and samples were all diluted in Medium 199. At least two dilutions of all samples were assayed in duplicate and samples from any one incubation were assessed in the same assay. The rabbit liver receptor assay had a sensitivity of $10-31 \mathrm{ng} / \mathrm{ml}$; within-assay variation was $3 \cdot 4-5 \cdot 0 \%$, assessed as standard deviations from differences between duplicates. For the rabbit mammary gland receptor assay these values were $9-52 \mathrm{ng} / \mathrm{ml}$ and $1 \cdot 7-3.8 \%$ respectively.

Radioimmunoassay of prolactin. The method of Hart (1973) was used, modified for doubleantibody precipitation. The rabbit anti-ovine prolactin serum was added in $100 \mu$, together with $100 \mu \mathrm{l}$ normal rabbit serum, diluted $1: 200$, and incubated with the standard or sample $(200 \mu \mathrm{l})$ plus ${ }^{125} \mathrm{I}$-labelled ovine prolactin $\left(200 \mu \mathrm{l}, 10000 \mathrm{c.p} . \mathrm{m}\right.$.) for $48 \mathrm{~h}$ at $4^{\circ} \mathrm{C}$. Donkey anti-rabbit serum (Guildhay Antisera, Guildford, Surrey, U.K.; $200 \mu$ l, diluted 1:40) was added and incubation continued for $24 \mathrm{~h}$ at $4^{\circ} \mathrm{C}$. The ligand was separated by centrifugation ( $900 \mathrm{~g}$ for $20 \mathrm{~min}$ ) and aspiration of the supernatant. The sensitivity was $0.2 \mathrm{ng} / \mathrm{ml}$ and the within-assay variation $5 \%$. 
Effect of dopamine on purified hormone preparations. Solutions of ovine prolactin, human growth hormone and human placental lactogen were prepared at 20 or $40 \mu \mathrm{g} / \mathrm{ml}$ (approx. $10^{-6}$ or $2 \times 10^{-6}$ $\mathrm{mol} / 1$ ), in buffer $(25 \mathrm{mmol} \mathrm{Tris} / 1,10 \mathrm{mmol} \mathrm{CaCl} / 1,0 \cdot 1 \%$ bovine serum albumin, $\mathrm{pH} 7 \cdot 4)$ containing ascorbic acid to prevent oxidation of dopamine $(100-300 \mathrm{mg} / \mathrm{l})$ and either no dopamine or $10^{-3} \mathrm{~mol}$ dopamine/l. The solutions were incubated in closed sterile glass vessels at room temperature or $37^{\circ} \mathrm{C}$ for various times (see 'Results'). In the time-course experiments, samples $(200 \mu 1)$ were withdrawn from the incubation tubes at the times specified. At the end of the incubation, solutions were stored frozen until their hormone content was assessed by radioreceptor assay or radioimmunoassay by comparison with controls or against freshly prepared standard hormone solutions. All hormones were weighed using a Cahn microbalance. Goat placental lactogen was supplied freeze-dried in the presence of sucrose. A solution containing $1 \mu \mathrm{g}$ prolactin equivalents $/ \mathrm{ml}$ as assessed by radioreceptor assay $\left(\sim 5 \times 10^{-8} \mathrm{~mol} / \mathrm{l}\right)$ was prepared in buffer containing $200 \mathrm{mg}$ ascorbic acid/1. Samples were frozen immediately or incubated for $24 \mathrm{~h}$ at $37^{\circ} \mathrm{C}$ with or without dopamine $\left(10^{-3} \mathrm{~mol} / \mathrm{l}\right)$ before freezing. Each treatment was replicated 3 times and samples were assayed as previously described.

\section{Results}

The amount of placental lactogen which could be detected by radioreceptor assay in the medium of incubations of bovine cotyledons was drastically reduced by $10^{-3} \mathrm{~mol}$ dopamine $/ 1$, but was not affected by lower concentrations of dopamine $\left(10^{-5}\right.$ or $\left.10^{-7} \mathrm{~mol} / \mathrm{l}\right)$ or by bromocriptine $\left(10^{-6}\right.$ $\mathrm{mol} / \mathrm{l}$; Text-fig. 1). The response to dopamine was not affected by collecting tissue in medium

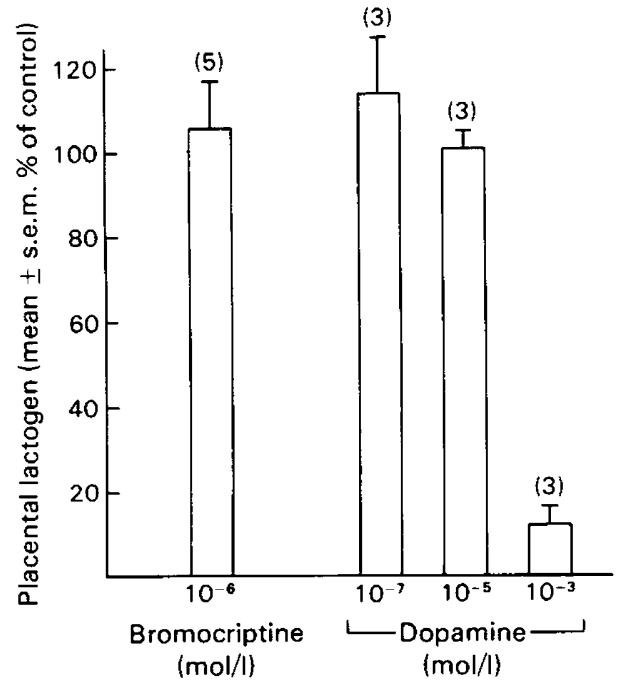

Text-fig. 1. Effect of bromocriptine or dopamine on placental lactogen detected by radioreceptor assay, using rabbit liver membranes and ${ }^{125}$ I-labelled ovine prolactin, in medium from incubations of bovine cotyledons as a percentage of the respective control incubations. Tissue from 5 cows was incubated with or without bromocriptine (mean \pm s.e.m. placental lactogen levels in the control cultures were $16 \cdot 0 \pm 1 \cdot 3,11 \cdot 7 \pm 2 \cdot 6,19 \cdot 4 \pm 6 \cdot 1,19 \cdot 2 \pm$ 4.0 and $41.9 \pm 2.6 \mathrm{ng} / \mathrm{mg} ; n=5$; results are expressed in ovine prolactin equivalents per $\mathrm{mg}$ wet weight of cotyledonary tissue). Tissue from 3 cows was incubated with or without dopamine (placental lactogen levels in the control cultures were 104.8 $\pm 2 \cdot 9,55.4 \pm 9.5$ and $11.7 \pm 1.1 \mathrm{ng} / \mathrm{mg}$ ). 
containing dopamine $\left(10^{-7} \mathrm{~mol} / \mathrm{l}\right)$, a procedure which facilitates the demonstration of the inhibition of prolactin secretion by dopamine in perfused columns of isolated anterior pituitary cells (see Yeo et al., 1979; F. J. Cunningham, personal communication). Similar results were obtained with cotyledonary tissues from goats (results not shown). In the initial experiments no steps were taken to prevent the oxidation of dopamine to melanin, but the addition of L-ascorbic acid (100 mg/l), while effectively preventing melanin formation, failed to increase the sensitivity of the response to dopamine.

When explants of goat cotyledons were killed before incubation by freezing on solid carbon dioxide, similar results were obtained. The amount of placental lactogen found in the medium $24 \mathrm{~h}$ later was $35 \cdot 3 \pm 2 \cdot 4$ (s.e.m.) $\mathrm{ng} / \mathrm{mg}$ wet weight of tissue in Medium 199 and $28 \cdot 3 \pm 2 \cdot 1 \mathrm{ng} / \mathrm{mg}$ in Medium $199+$ ascorbic acid $(n=5)$. Addition of dopamine $\left(10^{-3} \mathrm{~mol} / \mathrm{l}\right)$ to either medium reduced the placental lactogen to undetectable levels $(<3.6 \mathrm{ng} / \mathrm{mg})$. The effects of dopamine were, therefore, tested on homogenates of goat placenta. Dopamine added to the extraction medium or to the assay medium had no effect. However, when dopamine $\left(10^{-3} \mathrm{~mol} / \mathrm{l}\right)$ was incubated at $37^{\circ} \mathrm{C}$ with the homogenate for $24 \mathrm{~h}$ before the supernatant was prepared, the activity that could be detected was decreased by about $70 \%$. Dopamine added to the standard ovine prolactin just before the assay

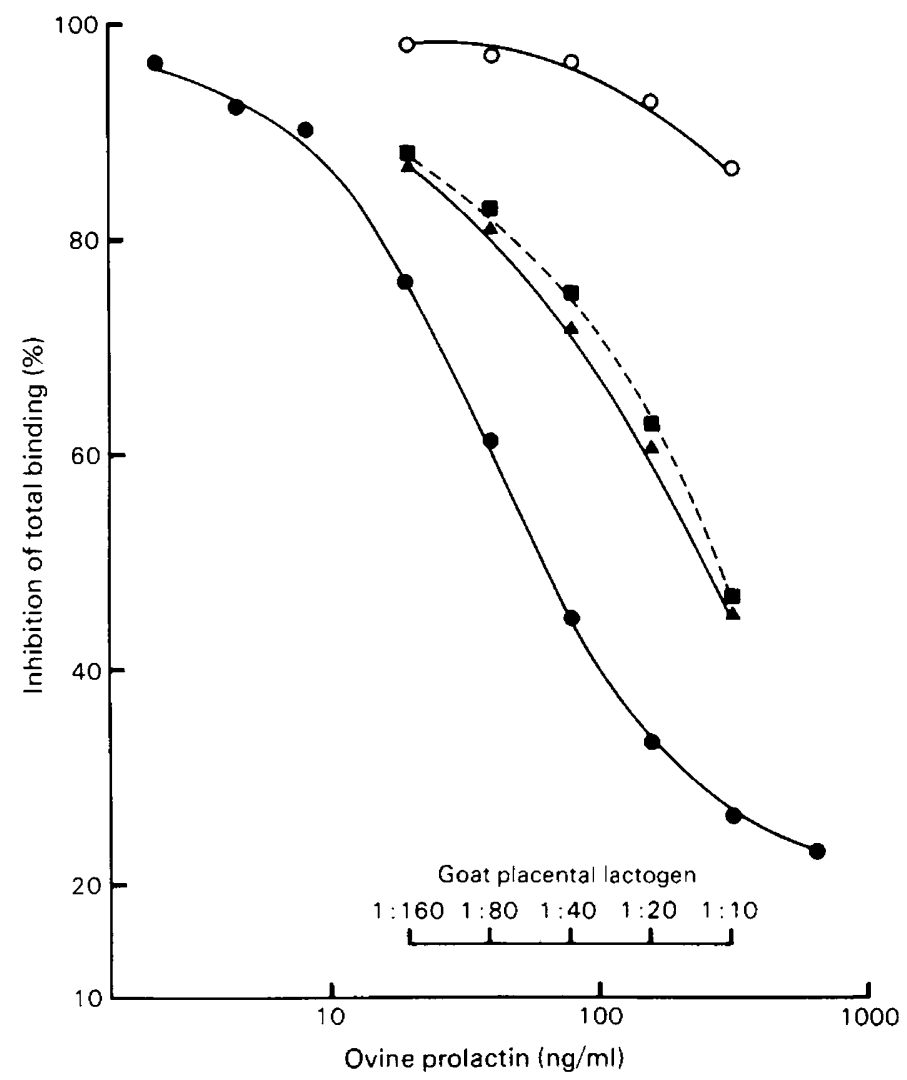

Text-fig. 2. Effect of dopamine $\left(10^{-3} \mathrm{~mol} / \mathrm{l}\right)$ on the binding activity in a radioreceptor assay using rabbit mammary gland membranes of goat placental lactogen $\left(1 \mu \mathrm{g} / \mathrm{ml}, 5 \times 10^{-8} \mathrm{~mol} / \mathrm{l}\right.$, in $25 \mathrm{mmol}$ Tris $/ 1,10 \mathrm{mmol} \mathrm{CaCl} / 1,0 \cdot 1 \% \mathrm{BSA}, 200 \mathrm{mg}$ ascorbic acid/1, $\mathrm{pH} 7 \cdot 4)$. The solution was frozen immediately $(\Delta)$ or incubated for $24 \mathrm{~h}$ at $37^{\circ} \mathrm{C}$ without $(\square)$ or with $(O)$ dopamine before dilution as indicated. The experiment was repeated 3 times, mean values are plotted and standard errors were less than $10 \%$. The standard curve for ovine prolactin $(\mathcal{O})$ is also shown. 
was set up slightly reduced its activity. Because reduction in the binding of placental lactogen could also be ascribed to proteolytic enzymes in the homogenate, a purified preparation of goat placental lactogen was also tested (Text-fig. 2). Incubation of this preparation at $37^{\circ} \mathrm{C}$ for $24 \mathrm{~h}$ resulted in a loss of activity of about $10 \%$. The addition of dopamine to the incubation medium increased the loss of activity to about $90 \%$.

Incubation for $24 \mathrm{~h}$ at $37^{\circ} \mathrm{C}$ with dopamine also affected the activity in the radioreceptor assay of purified preparations of ovine prolactin, human growth hormone and human placental lactogen $\left(20 \mu \mathrm{g} / \mathrm{ml}, 10^{-6} \mathrm{~mol} / \mathrm{l}\right)$. Using $10^{-3} \mathrm{~mol}$ dopamine $/ 1$, the ability of ovine prolactin and human growth hormone to compete with labelled hormone for receptors was reduced by $50 \%$ and $40 \%$ respectively (Text-fig. 3a, b). The effect on human placental lactogen was more marked and the dose-response curve was no longer parallel with the human placental lactogen standard (Text-fig. $3 c)$. When increasing amounts of dopamine were incubated at room temperature with human placental lactogen $\left(40 \mu \mathrm{g} / \mathrm{ml}, 2 \times 10^{-6} \mathrm{~mol} / 1\right)$ for $18 \mathrm{~h}$, the activity of the hormone was progressively reduced and totally abolished by $5.2 \times 10^{-2} \mathrm{~mol}$ dopamine/l (Text-fig. 3d). Differences in the effect of dopamine on the activity of ovine prolactin and human placental lactogen were also revealed by looking at the time-course of inactivation. At $37^{\circ} \mathrm{C}$ dopamine $\left(10^{-3}\right.$ $\mathrm{mol} / \mathrm{l}$ ) had inactivated $40 \%$ of a purified human placental lactogen preparation by $2 \mathrm{~h}$. The effect on ovine prolactin was slower and less drastic (Table 1). The effect of incubation for $18 \mathrm{~h}$ at $37^{\circ} \mathrm{C}$ with different amounts of dopamine on the activity of ovine prolactin in a radioimmunoassay was also tested. The immunological activity of ovine prolactin was reduced but not in a dose-dependent manner. The ovine prolactin still detectable in a solution prepared at $10 \mu \mathrm{g} / \mathrm{ml}$ was $65 \%$ at $5 \times 10^{-4}$ mol dopamine $/ 1,50 \%$ at $5 \times 10^{-3} \mathrm{~mol} / 1,67 \%$ at $10^{-2} \mathrm{~mol} / 1$ and $43 \%$ at $2 \times 10^{-2} \mathrm{~mol} / 1$, measured against a sheep prolactin standard incubated in the same way but without dopamine.

Table 1. Time course of inactivation of ovine prolactin and human placental lactogen $\left(20 \mu \mathrm{g} / \mathrm{ml}, 10^{-6}\right.$ $\mathrm{mol} / \mathrm{l})$ by dopamine $\left(10^{-3} \mathrm{~mol} / \mathrm{l}\right)$

\begin{tabular}{|c|c|c|c|c|c|c|}
\hline \multirow[b]{2}{*}{ Time (h) } & \multicolumn{3}{|c|}{ Ovine prolactin } & \multicolumn{3}{|c|}{ Human placental lactogen } \\
\hline & $\begin{array}{l}\text { Without } \\
\text { dopamine }\end{array}$ & $\begin{array}{c}\text { With } \\
\text { dopamine }\end{array}$ & $P$ & $\begin{array}{l}\text { Without } \\
\text { dopamine }\end{array}$ & $\begin{array}{c}\text { With } \\
\text { dopamine }\end{array}$ & $P$ \\
\hline 0 & 100 & $95+2.5$ & NS & 100 & $101+2 \cdot 9$ & NS \\
\hline 2 & $96+1 \cdot 5$ & $86+2 \cdot 4$ & NS & $115+4 \cdot 1$ & $59+6 \cdot 3$ & $<0.05$ \\
\hline 4 & $90+2 \cdot 4$ & $74+2.5$ & $<0.05$ & $103+4 \cdot 2$ & $44+1.9$ & $<0.01$ \\
\hline 8 & $80 \pm 7.5$ & $64 \pm 2 \cdot 6$ & NS & $59 \pm 0.8$ & $22 \pm 0.5$ & $<0.001$ \\
\hline
\end{tabular}

Results are expressed as a percentage of the hormone activity present at the start of the incubation (mean \pm s.e.m., $n=3$ ).

\section{Discussion}

Significant inhibition of prolactin secretion in vitro from anterior pituitary cells of rats is produced by $5 \times 10^{-8} \mathrm{~mol}$ dopamine/l and by $10^{-3} \mathrm{~mol}$ bromocriptine/l (Yeo et al., 1979). By contrast, reduction of the activity of bovine and goat placental lactogen in the medium of incubations of fetal cotyledonary placenta requires $10^{-3} \mathrm{~mol}$ dopamine/l, with no effect being produced by lower concentrations of dopamine or by $10^{-6} \mathrm{~mol}$ bromocriptine/l, the highest concentration it was possible to prepare in aqueous solution. Further experiments using goat placental tissue killed by freezing, an homogenate of goat placenta and purified goat placental lactogen indicate that dopamine does not reduce secretion rate of the hormone at this concentration but depresses the ability of placental lactogen to bind to its receptors. Addition of dopamine to the radioreceptor assay mixture had little or no effect, indicating that dopamine alters the structure or conformation of the hormone, rather than interfering directly in binding. 


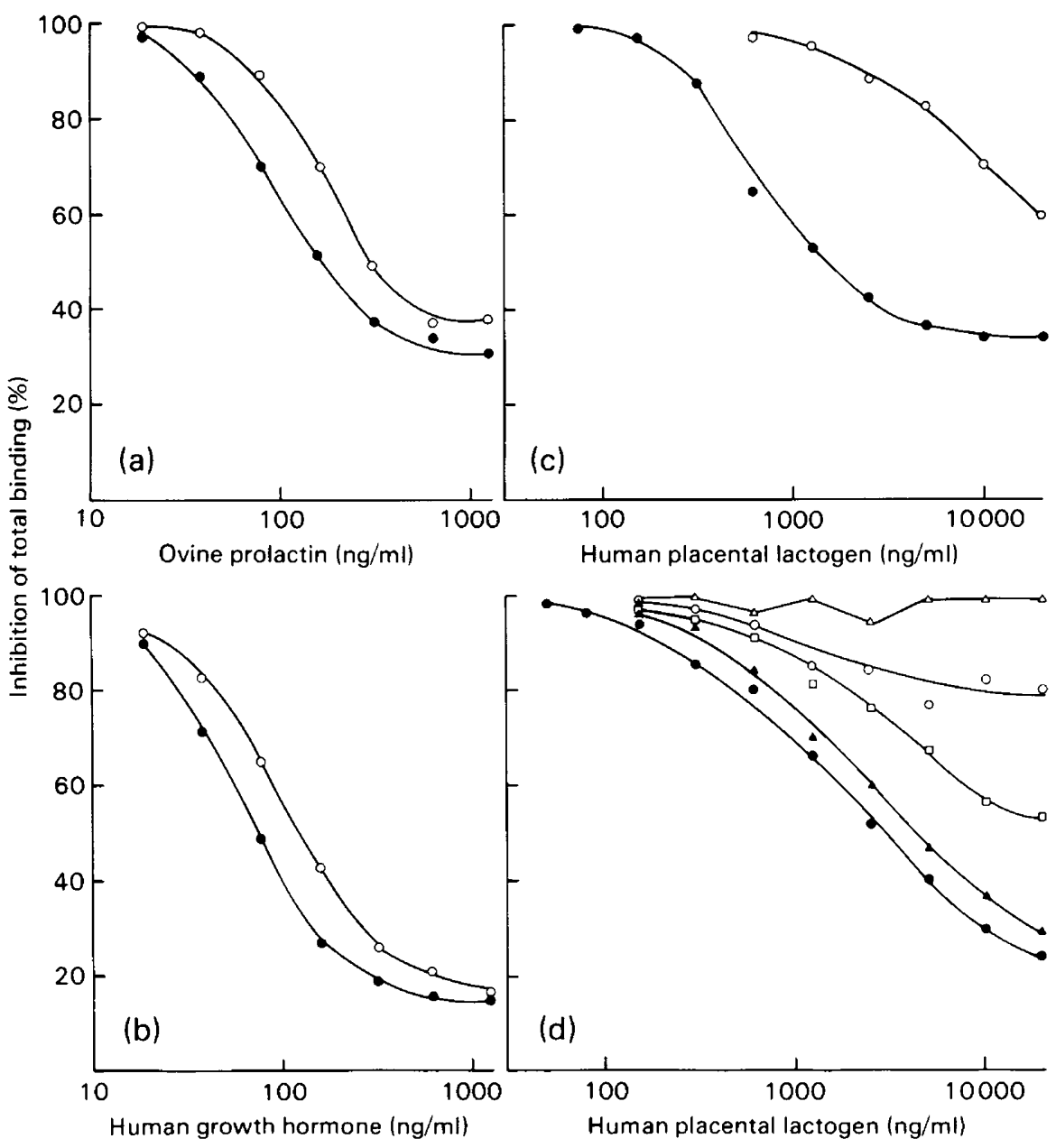

Text-fig. 3. Effect of dopamine on the binding activity in a radioreceptor assay using rabbit mammary gland membranes of ovine prolactin, human growth hormone and human placental lactogen. (a) Ovine prolactin $\left(20 \mu \mathrm{g} / \mathrm{ml}, \sim 10^{-6} \mathrm{~mol} / \mathrm{l}\right)$ incubated for $24 \mathrm{~h}$ at $37^{\circ} \mathrm{C}$ in buffer $(25$ $\mathrm{mmol}$ Tris $/ 1+10 \mathrm{mmol} \mathrm{CaCl} / 1,0 \cdot 1 \%$ BSA, $\mathrm{pH} 7 \cdot 4)+100 \mathrm{mg}$ ascorbic acid/l without (O) or with $(O)$ dopamine $\left(10^{-3} \mathrm{~mol} / \mathrm{l}\right)$ before dilution as indicated. (b) Human growth hormone (20 $\mu \mathrm{g} / \mathrm{ml}, \sim 10^{-6} \mathrm{~mol} / \mathrm{l}$ ) incubated as in (a) without $(O)$ or with $(O)$ dopamine. (c) Human placental lactogen $\left(20 \mu \mathrm{g} / \mathrm{ml}, \sim 10^{-6} \mathrm{~mol} / \mathrm{l}\right)$ incubated as in (a) without (O) or with $(O)$ dopamine. (d) Human placental lactogen $\left(40 \mu \mathrm{g} / \mathrm{ml}, \sim 2 \times 10^{-6} \mathrm{~mol} / \mathrm{l}\right)$ incubated for $18 \mathrm{~h}$ at room temperature in buffer without dopamine (O) or with dopamine at concentrations of $10^{-3}$ $\mathrm{mol} / \mathrm{l}(\Delta), 1.3 \times 10^{-2} \mathrm{~mol} / \mathrm{l}(\square), 2.6 \times 10^{-2} \mathrm{~mol} / 1(O), 5.2 \times 10^{-2} \mathrm{~mol} / 1(\Delta)$. The labelled hormone was ${ }^{125} \mathrm{I}$-ovine prolactin in (a), (c) and (d) and ${ }^{125} \mathrm{I}$-human growth hormone in (b). All points are means of duplicate determinations.

The effect of dopamine was also seen on a purified preparation of human placental lactogen. The effect was dependent on the concentration of dopamine and on the time and temperature of exposure. This suggests that the results of Macaron et al. (1978), using a radioimmunoassay after incubation of explants of human placenta for $3 \mathrm{~h}$, could be explained by a similar effect on hormone activity rather than secretion rate, although it is not clear why pimozide prevented the effect of dopamine. 
The activity of ovine prolactin and human growth hormone in a radioreceptor assay and of ovine prolactin in a radioimmunoassay were also affected by dopamine, but to a much smaller extent. Dopamine may therefore be a useful reagent for studies of structure-activity relationships in this group of hormones.

It remains uncertain why administration of bromocriptine is sometimes associated with a fall in the level of circulating placental lactogen in sheep and goats, but a direct effect via dopamine receptors appears to be excluded.

Dr I. C. Hart kindly supplied the antisera to ovine prolactin. G.T. received financial support from the International Atomic Energy Agency and the Icelandic Student Loan Fund.

\section{References}

Buttle, H.L., Cowie, A.T., Jones, E.A. \& Turvey, A. (1979) Mammary growth during pregnancy in hypophysectomized or bromocriptine-treated goats. J. Endocr. 80, 343-351.

Forsyth, I.A. \& Hayden, T.J. (1980) Effects of dopamine and arginine on bovine placental lactogen production in vitro. $J$. Endocr. 85, 318.

Hart, I.C. (1973) Basal levels of prolactin in goat blood measured throughout a $24-\mathrm{h}$ period by a rapid double antibody-solid phase radioimmunoassay. J. Dairy Res. 40, 235-245.

Hayden, T.J., Thomas, C.R., Smith, S.V. \& Forsyth, I.A. (1980) Placental lactogen in the goat in relation to stage of pregnancy, number of foetuses, metabolites, progesterone and time of day. J. Endocr. 86, 279-290.

Lowe, K.C., Beck, N.F.G., McNaughton, D.C., Gluckman, P.D., Kaplan, S.L., Grumbach, M.M. \& Nathanielsz, P.W. (1979) Effect of long-term bromocriptine infusion on plasma prolactin and ovine chorionic somatomammotropin in the pregnant ewe and fetal sheep. Am. J. Obstet. Gynec. 135, 773-777.

Macaron, C., Famuyiwa, O. \& Singh, S.P. (1978) In vitro effect of dopamine and pimozide on human chorionic somatomammotropin (hCS) secretion. J. clin. Endocr. Metab. 47, 168-170.
Martal, J. \& Lacroix, M.-C. (1978) Production of chorionic somatomammotropin (oCS), fetal growth and growth of the placenta and the corpus luteum in ewes treated with 2-bromoergocriptine. Endocrinology 103, 193-199.

Marti-Henneberg, C., Gluckman, P.D., Isaac, R., Kaplan, S.L. \& Grumbach, M.M. (1981) Hormone ontogeny in the ovine fetus. XII. The dopaminergic regulation of growth hormone and chorionic somatomammotropin release. Endocrinology 109, 1355-1359.

Parke, L. \& Forsyth, I.A. (1975) Assay of lactogenic hormones using receptors isolated from rabbit liver. Endocr. Res. Commun. 2, 137-149.

Shiu, R.P.C., Kelly, P.A. \& Friesen, H. (1973) Radioreceptor assay for prolactin and other lactogenic hormones. Science, N.Y. 180, 968-969.

Yeo, T., Thorner, M.O., Jones, A., Lowry, P.J. \& Besser, G.M. (1979) The effects of dopamine, bromocriptine, legotrile and metaclopramide on prolactin release from constantly perfused columns of isolated rat pituitary cells. Clin. Endocr. 10, 123-130.

Received 17 November 1983 